\title{
Asupan zat gizi mikro dengan fungsi kognitif pada lanjut usia
}

\section{Micronutrients intake and cognitive function of the elderly}

\author{
Ade Rahmawati ${ }^{1}$, I Dewa Putu Pramantara ${ }^{2}$, Martalena Br. Purba ${ }^{3}$
}

\begin{abstract}
Background: The elderly population in Indonesia increased significantly in the last two decades as the life expectancy increase from 66.7 years to 70.5 years with impact to the emergence of diseases in the elderly. One of them is degradation of cognitive function that may disrupt productivity, daily activities, and quality of life of the elderly. Adequate micronutrients intake may help in maintaining cognitive function.

Objective: To identify association between intake of micronutrients (vitamin B6, folate, vitamin C, and vitamin E) and cognitive function of the elderly at Among Yuswa Club of Banteng Baru, District of Sleman.

Method: This was an observational study with cross sectional design. Subjects were elderly people at Among Yuswa Club of Banteng Baru, District of Sleman. Data on cognitive function was obtained using the Mini Mental State Examination (MMSE) and intake of micronutrients were collected using Semi Qualitative Food Frequency Questionnaire (SQFFQ). The data was analysed by chi square and logistic regression tests.

Result: The result showed statistically significant association between cognitive function and intake of vitamin B6 $(p=0.010 ; R P=2.514 ; 95 \% C l=1.133-5.575)$, vitamin $C$ intake $(p=0.011 ; R P=3.039 ; 95 \% C l=1.454-6.353)$ and vitamin $E$ intake $(p=0.021 ; R P=1.266 ; 95 \% \mathrm{Cl}=1.057-1.516)$; meanwhile folate intake has no significant association with cognitive function ( $p>0.05)$.

Conclusion: There were significant associations between intake of vitamin B6, vitamin $C$ and vitamin $E$ with cognitive function. There was no significant association found between intake of folate and cognitive function in the elderly.
\end{abstract}

KEY WORDS micronutrients, cognitive function, elderly

\begin{abstract}
ABSTRAK
Latar belakang: Dua dekade terakhir ini terdapat peningkatan populasi penduduk usia lanjut di Indonesia, karena meningkatnya usia harapan hidup dari 66,7 tahun menjadi 70,5 tahun yang berdampak timbulnya penyakit pada lansia. Salah satunya adalah penurunan fungsi kognitif yang dapat mengganggu produktivitas, aktivitas sehari-hari, dan kualitas hidup lansia. Asupan zat gizi mikro yang cukup akan membantu memelihara kemampuan fungsi kognitif.

Tujuan: Mengetahui hubungan antara asupan gizi mikro (vitamin B6, folat, vitamin C, dan vitamin E) terhadap fungsi kognitif pada lanjut usia di Paguyuban Among Yuswa Banteng Baru Kabupaten Sleman.

Metode: Jenis penelitian ini adalah observasional dengan rancangan cross sectional. Subjek penelitian ini adalah lansia yang ada di paguyuban Among Yuswa Banteng Baru Kabupaten Sleman. Data fungsi kognitif diukur menggunakan mini-mental state examination (MMSE). Data asupan zat gizi mikro (vitamin B6, folat, vitamin C, and vitamin E) diukur menggunakan semi quantitatif food frequency questionnaire (SQFFQ). Analisis bivariat menggunakan Chi Square dan multivariat menggunakan regresi logistik.

Hasil: Hasil analisis menunjukkan bahwa variabel yang bermakna secara statistik terhadap fungsi kognitif adalah asupan vitamin $B 6(p=0,019 ; R P=2,514 ; 95 \% C l: 1,133-5,575)$, asupan vitamin $C(p=0,011 ; R P=3,039 ; 95 \% C l: 1,454$ 6,353), dan asupan vitamin $E(p=0,021 ; R P=1,266 ; 95 \% C l: 1,057-1,516)$. Sedangkan asupan folat menunjukkan tidak ada hubungan bermakna ( $p>0,05)$.

Kesimpulan: Ada hubungan yang bermakna antara asupan vitamin B6, vitamin $C$, dan vitamin $E$ dengan fungsi kognitif. Tidak terdapat hubungan yang bermakna antara asupan folat dengan fungsi kognitif pada lanjut usia.
\end{abstract}

KATA KUNCI: zat gizi mikro, fungsi kognitif, lanjut usia

\section{PENDAHULUAN}

Populasi penduduk lanjut usia (lansia) di dunia terus meningkat tanpa disadari. Dengan adanya kemajuan teknologi kedokteran serta perbaikan pelayanan kesehatan dan gizi yang lebih baik, diperkirakan mulai tahun 2010 akan terjadi ledakan jumlah penduduk lanjut usia. Sementara itu, dalam dua dekade terakhir ini terdapat peningkatan populasi penduduk usia lanjut (usila) di Indonesia. Indonesia termasuk negara yang memasuki era penduduk berstruktur usia lanjut (aging-structured population), berdasarkan prediksi akan menjadi negara dengan kecepatan pertumbuhan lansia tertinggi di dunia. Usia harapan hidup (life expectancy) ratarata penduduk dunia secara bertahap meningkat, sehingga jumlah penduduk lansia yang mengalami penurunan fungsi

\footnotetext{
${ }^{1}$ Fakultas Kesehatan Masyarakat, Univesitas Wiralodra Indramayu, Jl. Ir.H.Juanda KM.3, Indramayu, e-mail: aderahma86@gmail.com

${ }^{2}$ Bagian Penyakit Dalam Rumah Sakit Umum Pusat Dr. Sardjito, Jl. Kesehatan No 1, Yogyakarta 55281, e-mail: dewapramantara@yahoo. com

${ }^{3}$ Instalasi Gizi Rumah Sakit Umum Pusat Dr. Sardjito, JI. Kesehatan No 1, Yogyakarta 55281, e-mail: martalena_purba@yahoo.com
} 
kognitif juga pasti akan meningkat secara proporsional $(1,2)$.

Asupan zat gizi adalah salah satu faktor yang sangat penting dalam meningkatkan kesehatan lansia dan menurunkan berbagai risiko terkait dengan proses penuaan dan penurunan fungsi kognitif. Beberapa penelitian menyebutkan bahwa asupan zat gizi mikro yang cukup akan membantu memelihara kemampuan fungsi kognitif pada subjek lansia. Hasil penelitian di Madrid menyebutkan bahwa ada beberapa vitamin yang berhubungan dengan fungsi kognitif antara lain vitamin B1, folat, riboflavin, dan vitamin $C$, selain itu juga suplementasi vitamin $C$ dan $\mathrm{E}$ dapat memberi efek protektif terhadap penurunan fungsi kognitif. Vitamin $C$ merupakan antioksidan yang berperan dalam menangkal stres oksidatif. Vitamin C juga dibutuhkan dalam reaksi hidrolisis yaitu sintesis amin-amin biogenik dalam sistem saraf pusat dan medula adrenal. Vitamin E berfungsi sebagai antioksidan terhadap membran sel. Vitamin E dapat memperbaiki stres oksidatif dan resistensi insulin sehingga dapat menurunkan dan menghalangi perkembangan komplikasi kronik diabetes mellitus. Penelitian di Amerika menyatakan bahwa defisiensi asam folat, vitamin B6, dan vitamin B12 juga dapat menyebabkan kerusakan pada pembuluh darah otak dan menyebabkan gangguan fungsi kognitif. Fungsi kognitif yang baik sangat diperlukan agar seseorang dapat meningkatkan kualitas hidup terutama optimalisasi status fungsional, memulihkan produktivitas, kreativitas, dan perasaan bahagianya $(2,3,4,5)$. Tujuan penelitian ini yaitu untuk mengetahui hubungan antara asupan zat gizi mikro (vitamin B6, folat, vitamin C, dan vitamin E) dengan fungsi kognitif pada lanjut usia di Paguyuban Among Yuswa Banteng Baru Kabupaten Sleman.

\section{BAHAN DAN METODE}

Penelitian ini merupakan penelitian cross sectional dengan jenis penelitian kuantitatif. Penelitian dilaksanakan di paguyuban lansia Among Yuswa Banteng Baru, Kecamatan Ngaglik, Kabupaten Sleman dari bulan Desember 2010 sampai dengan Januari 2011. Paguyuban Among Yuswa merupakan paguyuban lansia yang melaksanakan kegiatan-kegiatan yang dilakukan oleh para lansia sehingga lansia tetap aktif. Pemilihan populasi penelitian di paguyuban Among Yuswa dengan alasan untuk memperoleh subjek penelitian yang seragam dari tingkat pendidikan dan status sosial ekonomi.

Subjek penelitian adalah semua lansia paguyuban Among Yuswa dengan kriteria inklusi yaitu berusia lebih dari atau sama dengan 60 tahun dan bertempat tinggal di Banteng Baru. Kriteria eksklusinya adalah lansia dengan gangguan penglihatan, gangguan pendengaran, kelainan fisik berat, riwayat tumor otak, penyakit stroke berdasarkan wawancara dan dengan melihat riwayat penyakit yang tertera di dalam data Paguyuban Among Yuswa. Besar sampel penelitian ini diperoleh melalui perhitungan dengan menggunakan rumus sampel tunggal untuk estimasi proporsi dengan tingkat kepercayaan (Za) 95\%, data prevalensi gangguan kognitif sebesar $47,25 \%$, dan ketepatan relatif $10 \%$ sehingga diperoleh sampel minimal sebesar 96 orang (6). Sampel penelitian ini menggunakan total populasi yaitu seluruh lansia yang ada di Paguyuban Among Yuswa Banteng Baru yang berjumlah 146 orang, tetapi hanya 99 orang yang memenuhi kriteria inklusi dan eksklusi.

Variabel terikat dalam penelitian ini yaitu fungsi kognitif, variabel bebas yaitu asupan zat gizi (vitamin B6, folat, vitamin $C$, dan vitamin E), dan variabel luarnya antara lain umur, jenis kelamin, pendidikan, status gizi, status perkawinan, hipertensi, dan diabetes mellitus.

Skrining pada lansia dilakukan dengan menggunakan mini-mental state examination (MMSE) untuk mengidentifikasi masalah fungsi kognitif pada lansia. MMSE terdiri dari 30 pertanyaan, untuk setiap jawaban "ya" diberi skor 1 dan setiap jawaban "tidak" diberi skor 0 . Kategori fungsi kognitif dibagi menjadi dua yaitu mengalami gangguan kognitif jika skor MMSE kurang dari atau sama dengan 23 dan tidak mengalami gangguan kognitif jika skor MMSE sama dengan 24-30 (7). Penilaian fungsi kognitif dilakukan oleh peneliti dan enumerator.

Penilaian asupan zat gizi (vitamin B6, folat, vitamin $\mathrm{C}$, dan vitamin $\mathrm{E}$ ) menggunakan metode semi quantitative food frequency quessionnaire (SQFFQ), yaitu menanyakan bahan makanan dan suplemen yang dikonsumsi dalam 3 bulan terakhir. Penilaian asupan zat gizi ini dilakukan satu kali oleh peneliti dan enumerator, selanjutnya diolah menggunakan program nutrisurvey. Asupan vitamin B6 dikategorikan adekuat bila asupan vitamin B6 lebih dari atau sama dengan $1,7 \mathrm{mg}$ untuk laki-laki dan $1,5 \mathrm{mg}$ untuk perempuan (8). Asupan folat dikategorikan menjadi adekuat bila asupan folat lebih dari atau sama dengan 400 $\mu \mathrm{g}$ dan tidak adekuat bila asupan folat kurang dari 400 $\mu \mathrm{g}$. Asupan vitamin $\mathrm{C}$ dikategorikan adekuat bila asupan vitamin C lebih dari atau sama dengan $90 \mathrm{mg}$ untuk laki-laki dan $75 \mathrm{mg}$ untuk perempuan. Asupan vitamin $\mathrm{E}$ dikategorikan menjadi adekuat bila asupan vitamin $\mathrm{E}$ lebih dari atau sama dengan $15 \mathrm{mg}$ dan tidak adekuat bila asupan vitamin E kurang dari $15 \mathrm{mg}(9)$.

Status gizi subjek penelitian ditentukan dengan menggunakan rumus body mass armspan (BMA) yaitu berat badan aktual $(\mathrm{kg})$ dibagi rentang lengan $\left(\mathrm{m}^{2}\right)$. Timbangan injak elektrik merk Sayota dengan tingkat ketelitian $0,1 \mathrm{~kg}$ untuk mengukur berat badan dan pita meteran dengan tingkat ketelitian $0,1 \mathrm{~cm}$ untuk mengukur rentang lengan. Status gizi berdasarkan BMA dikategorikan menjadi malnutrisi (wanita $<18,7$; laki-laki $<20,1$ ), lebih (wanita >22,8; laki-laki >25,1), dan baik (wanita $=18,7-22,8$; laki-laki $=20,1-25)(9)$. 
Data penelitian ini diambil oleh peneliti dibantu beberapa orang enumerator yang berlatar belakang pendidikan S2 Gizi Kesehatan dan telah mendapatkan pengarahan sebelum penelitian sehingga mempunyai persepsi yang sama tentang teknis penggunaan kuesioner dan teknis pelaksanaan di lapangan. Data dan informasi yang terkumpul dianalisis secara bertahap melalui analisis bivariat (Chi Square) dan multivariat (regresi logistik). Penelitian terhadap subjek dilaksanakan setelah memperoleh ethical clearance dari Komite Etik Fakultas Kedokteran Universitas Gadjah Mada dan setelah mendapat persetujuan dan kesediaan untuk menjadi subjek penelitian yang ditunjukkan dengan mengisi dan menandatangani informed consent oleh responden.

\section{HASIL}

Subjek penelitian sebagian besar berumur antara 6070 tahun sebanyak 72 subjek $(72,8 \%)$ dan rata-rata umur adalah 66,34 tahun $(\mathrm{SD} \pm 5,34)$ dengan umur termuda 60 tahun dan umur tertua 82 tahun. Sebagian besar subjek penelitian berjenis kelamin perempuan $(64,6 \%)$, latar belakang pendidikannya adalah sarjana/perguruan tinggi $(59,6 \%)$, memiliki pasangan $(68,7 \%)$, dan sudah tidak bekerja/pensiun (91,9\%) (Tabel 1).

Dari hasil analisis (Tabel 2) diperoleh bahwa tidak ada hubungan yang bermakna antara faktor-faktor luar yaitu umur, jenis kelamin, pendidikan, status perkawinan,
Tabel 1. Distribusi karakteristik subjek penelitian

\begin{tabular}{|c|c|c|}
\hline Karakteristik & Jumlah (n) & Persentase (\%) \\
\hline \multicolumn{3}{|l|}{ Jenis kelamin } \\
\hline Wanita & 64 & 64,6 \\
\hline Laki-laki & 35 & 35,4 \\
\hline \multicolumn{3}{|l|}{ Umur (tahun) } \\
\hline $60-70$ & 72 & 72,8 \\
\hline $71-80$ & 26 & 26,2 \\
\hline$>80$ & 1 & 1 \\
\hline \multicolumn{3}{|l|}{ Pendidikan } \\
\hline SMP & 4 & 4 \\
\hline SMA & 36 & 36,5 \\
\hline Perguruan tinggi & 59 & 59,6 \\
\hline \multicolumn{3}{|l|}{ Status perkawinan } \\
\hline Menikah & 68 & 68,7 \\
\hline Janda & 28 & 28,3 \\
\hline Duda & 3 & 3 \\
\hline \multicolumn{3}{|l|}{ Pekerjaan } \\
\hline Pensiunan & 91 & 91,9 \\
\hline Wiraswasta & 8 & 8,1 \\
\hline \multicolumn{3}{|l|}{ Hipertensi } \\
\hline Ya & 18 & 18,2 \\
\hline Tidak & 81 & 81,8 \\
\hline \multicolumn{3}{|l|}{ Diabetes } \\
\hline Ya & 15 & 15,2 \\
\hline Tidak & 84 & 84,8 \\
\hline \multicolumn{3}{|c|}{ Status gizi (BMA $\mathrm{kg} / \mathrm{m}^{2}$ ) } \\
\hline Malnutrisi & 70 & 70,7 \\
\hline Baik & 29 & 29,3 \\
\hline \multicolumn{3}{|l|}{ Fungi kognitif } \\
\hline Gangguan & 20 & 20,2 \\
\hline Normal & 79 & 79,8 \\
\hline
\end{tabular}

Tabel 2. Hubungan faktor-faktor luar dengan fungsi kognitif

\begin{tabular}{|c|c|c|c|c|c|c|c|c|}
\hline \multirow{3}{*}{ Variabel } & \multicolumn{4}{|c|}{ Fungsi kognitif } & \multirow{2}{*}{\multicolumn{2}{|c|}{ Total }} & \multirow{3}{*}{$\mathbf{p}$} & \multirow{3}{*}{$\begin{array}{c}\text { RP } \\
(95 \% \mathrm{Cl})\end{array}$} \\
\hline & \multicolumn{2}{|c|}{ Terganggu } & \multicolumn{2}{|c|}{ Tidak terganggu } & & & & \\
\hline & $\mathbf{n}$ & $\%$ & $\mathbf{n}$ & $\%$ & $\mathbf{n}$ & $\%$ & & \\
\hline \multicolumn{9}{|l|}{ Umur (tahun) } \\
\hline$\geq 71$ & 16 & 16,2 & 60 & 60,6 & 76 & 76,8 & 1,0 & 1,267 \\
\hline$\leq 70$ & 4 & 4,0 & 19 & 19,2 & 23 & 23,2 & & $(0,377-4,252)$ \\
\hline \multicolumn{9}{|l|}{ Jenis kelamin } \\
\hline Wanita & 11 & 11,1 & 53 & 53,5 & 64 & 64,6 & 0,312 & 0,600 \\
\hline Laki-laki & 9 & 9,1 & 26 & 26,3 & 35 & 35,4 & & $(0,221-1,627)$ \\
\hline \multicolumn{9}{|l|}{ Pendidikan } \\
\hline SMP/SMA & 9 & 9,1 & 31 & 31,3 & 40 & 40,4 & 0,639 & 1,267 \\
\hline PT & 11 & 11,1 & 48 & 48,5 & 59 & 59,6 & & $(0,471-3,409)$ \\
\hline \multicolumn{9}{|c|}{ Status perkawinan } \\
\hline Sendiri & 7 & 7,1 & 23 & 23,2 & 30 & 30,3 & 0,609 & 1,311 \\
\hline Menikah & 13 & 13,1 & 56 & 56,6 & 69 & 69,7 & & $(0,464-3,706)$ \\
\hline \multicolumn{9}{|l|}{ Status gizi } \\
\hline Malnutrisi & 14 & 14,1 & 56 & 56,5 & 70 & 70,7 & 0,938 & 1,034 \\
\hline Baik & 6 & 6,1 & 23 & 23,2 & 29 & 29,3 & & $(0,441-2,474)$ \\
\hline \multicolumn{9}{|l|}{ Hipertensi } \\
\hline $\mathrm{Ya}$ & 6 & 6,1 & 12 & 12,1 & 18 & 18,2 & 0,190 & 2,393 \\
\hline Tidak & 14 & 14,1 & 67 & 67,7 & 81 & 81,8 & & $(0,768-7,457)$ \\
\hline \multicolumn{9}{|l|}{ Diabetes } \\
\hline Ya & 3 & 3,0 & 12 & 12,1 & 15 & 15,1 & 1,0 & 0,985 \\
\hline Tidak & 17 & 17,2 & 67 & 67,7 & 84 & 84,9 & & $(0,250-3,887)$ \\
\hline
\end{tabular}

Keterangan: fungsi kognitif terganggu= nilai MMSE $\leq 23$

fungsi kognitif tidak terganggu= nilai MMSE $24-30$ 
Tabel 3. Analisis hubungan asupan vitamin B6, folat, vitamin C, dan vitamin E dengan status kognitif

\begin{tabular}{|c|c|c|c|c|c|c|c|c|}
\hline \multirow{3}{*}{ Asupan } & \multicolumn{4}{|c|}{ Status kognitif } & \multirow{2}{*}{\multicolumn{2}{|c|}{ Total }} & \multirow{3}{*}{$\mathbf{p}$} & \multirow{3}{*}{$\begin{array}{c}\mathbf{R P} \\
(95 \% \mathrm{Cl})\end{array}$} \\
\hline & \multicolumn{2}{|c|}{ Terganggu } & \multicolumn{2}{|c|}{ Tidak terganggu } & & & & \\
\hline & $n$ & $\%$ & $\mathbf{n}$ & $\%$ & $\mathbf{n}$ & $\%$ & & \\
\hline \multicolumn{9}{|l|}{ Vitamin B6 } \\
\hline Kurang & 12 & 12,1 & 25 & 25,3 & 37 & 37,4 & \multirow[t]{2}{*}{0,019} & 2,514 \\
\hline Baik & 8 & 8,1 & 54 & 54,5 & 62 & 62,6 & & $(1,133-5,575)$ \\
\hline \multicolumn{9}{|l|}{ Folat } \\
\hline Kurang & 19 & 19,1 & 69 & 69,7 & 88 & 88,9 & \multirow[t]{2}{*}{0,454} & 2,375 \\
\hline Baik & 1 & 1,0 & 10 & 10,1 & 11 & 11,1 & & $(0,351-16,05)$ \\
\hline \multicolumn{9}{|l|}{ Vitamin C } \\
\hline Kurang & 9 & 9,1 & 12 & 12,1 & 21 & 21,2 & \multirow[t]{2}{*}{0,011} & 3,039 \\
\hline Baik & 11 & 11,1 & 67 & 67,7 & 78 & 78,8 & & $(1,454-6,353)$ \\
\hline \multicolumn{9}{|l|}{ Vitamin E } \\
\hline Kurang & 3 & 3,0 & 34 & 34,3 & 37 & 37,4 & \multirow[t]{2}{*}{0,021} & 1,266 \\
\hline Baik & 17 & 17,2 & 45 & 45,5 & 62 & 62,6 & & $(1,057-1,516)$ \\
\hline
\end{tabular}

Keterangan: fungsi kognitif terganggu= nilai MMSE $\leq 23$

fungsi kognitif tidak terganggu= nilai MMSE $24-30$

Tabel 4. Analisis multivariat faktor risiko terhadap fungsi kognitif

\begin{tabular}{ccccccc}
\hline \multirow{2}{*}{ Variabel } & Koef & \multirow{2}{*}{ SE } & Exp & \multicolumn{2}{c}{$\mathbf{9 5 \% C l}$} & \multirow{2}{*}{$\mathbf{\text { (B) }}$} \\
\cline { 5 - 6 } & & & (B) & Lower & Upper & \\
\hline Vitamin C (kurang) & 1,232 & 0,574 & 3,428 & 1,114 & 10,552 & 0,032 \\
Vitamin B6 (kurang) & 0,983 & 0,546 & 2,672 & 0,916 & 7,799 & 0,072 \\
Hipertensi & 0,806 & 0,634 & 2,238 & 0,646 & 7,760 & 0,204 \\
Vitamin E (kurang) & 0,460 & 0,857 & 1,584 & 0,296 & 8,489 & 0,591 \\
\hline Keterangan: Koef (B) & $=$ koefesien B & & & & \\
SE & $=$ standart error & & & & \\
Exp (B) & $=$ expects of B & & & \\
Cl & $=$ confidence Interval & & & \\
p & $=$ p-value & & & &
\end{tabular}

status gizi, hipertensi, dan diabetes dengan fungsi kognitif $(p>0,05)$.

Rata-rata asupan vitamin B6 subjek sebesar $1,66 \pm 0,84 \mathrm{mg}$ dengan asupan terendah $0,3 \mathrm{mg}$ dan tertinggi $5,3 \mathrm{mg}$. Rata-rata asupan folat sebesar $160,73 \pm 103,19 \mu \mathrm{g}$ dengan asupan terendah 42,4 $\mu$ g dan tertinggi 549,2 $\mu \mathrm{g}$. Rata-rata asupan vitamin C sebesar 161,76 $\pm 105,22 \mathrm{mg}$ dengan asupan terendah 30,4 mg dan tertinggi 495,3

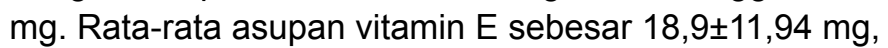
asupan terendah $8,6 \mathrm{mg}$ dan tertinggi $74,3 \mathrm{mg}$. Sebagian besar subjek penelitian memiliki asupan baik untuk vitamin B6, vitamin $\mathrm{C}$, dan vitamin $\mathrm{E}$ berturut-turut sebanyak 62 orang $(62,6 \%), 78$ orang $(78,8 \%)$, dan 62 orang $(62,6 \%)$. Sedangkan asupan folat sebagian besar subjek $(88,9 \%)$ tergolong kurang.

Hasil analisis tabulasi silang (Tabel 3) antara asupan vitamin B6, vitamin $C$, dan vitamin $E$ dengan fungsi kognitif menunjukkan adanya hubungan yang bermakna $(p<0,05)$. Sedangkan folat tidak menunjukkan hubungan yang bermakna $(p>0,05)$. Berdasarkan hasil analisis bivariat, ada empat variabel yang dapat dianalisis lebih lanjut dalam analisis multivariat. Variabel tersebut adalah vitamin B6, vitamin C, vitamin E, dan hipertensi (Tabel 4). Hasil analisis regresi logistik, didapatkan bahwa asupan vitamin C yang kurang merupakan faktor risiko terhadap terjadinya gangguan fungsi kognitif. Lansia dengan asupan vitamin $\mathrm{C}$ yang kurang memiliki risiko 3,428 kali mengalami gangguan fungsi kognitif dibandingkan lansia dengan asupan vitamin $\mathrm{C}$ yang cukup.

\section{BAHASAN}

\section{Hubungan antara variabel luar dengan status kognitif}

Dari hasil analisis didapatkan bahwa variabel luar (umur, jenis kelamin, pendidikan, status perkawinan, status gizi, hipertensi, dan diabetes) tidak memiliki hubungan bermakna dengan fungsi kognitif $(p>0,05)$. Pada penelitian ini sebagian besar subjek penelitian mempunyai latar belakang pendidikan yang tinggi yaitu sarjana bahkan sebagian subjek berlatar belakang pendidikan magister. Kondisi tersebut selain mempengaruhi status income, juga mempengaruhi kebiasaan membaca dan menulis, sehingga sel-sel otak tetap aktif dan laju penurunan fungsi kognitif dapat dikurangi (10). Hasil penelitian di Amerika menunjukkan bahwa pendidikan memiliki efek langsung terhadap struktur otak, meningkatkan jumlah sinaps, dan vaskularisasi darah ke otak 
(11). Pendidikan mempengaruhi kapasitas otak dan hasil tes fungsi kognitif, pendidikan tinggi berkorelasi terhadap income yang tinggi (12). Penelitian di Irlandia menyatakan bahwa pendidikan yang rendah mempengaruhi kapasitas otak seseorang, sehingga pada umumnya performa seseorang dalam tes fungsi kognitif menunjukkan skor yang cenderung rendah (13).

Status perkawinan tidak menunjukkan hubungan yang bermakna dengan fungsi kognitif, karena sebagian besar lansia masih memiliki pasangan dan hidup bersama keluarga, sehingga tidak merasa kesepian atau sendiri di masa tuanya dan tetap berpartisipasi dalam kegiatan sosial. Penelitian di Austria menunjukkan bahwa seseorang yang tidak memiliki pasangan dan tidak pernah menikah pada umumnya tidak mempunyai seseorang untuk membantu dalam kondisi stres dan depresi sehingga hal ini akan berpengaruh terhadap fungsi kognitifnya (14). Status perkawinan diduga berpengaruh terhadap fungsi kognitif, seperti hasil penelitian di Portugal bahwa seseorang yang hidup sendiri atau kehilangan pasangan akan berpengaruh terhadap penurunan fungsi kognitif (15).

Pada penelitian ini, umur subjek tidak berpengaruh terhadap terjadinya gangguan fungsi kognitif, karena sebagian besar umur subjek penelitian masih berada dalam rentang umur 60-70 tahun. Hal ini tidak sejalan dengan penelitian yang dilakukan di Austria, bahwa ada hubungan antara faktor usia dengan fungsi kognitif seseorang, di mana makin lanjut usia maka kemampuan untuk tes mental dan fungsi kognitif makin menurun (14). Seseorang yang berusia di atas 80 tahun terdapat lebih banyak kemunduran intelektual (7). Hasil penelitian di Portugal menunjukkan bahwa penurunan fungsi kognitif akan meningkat dengan bertambahnya umur seseorang, pada kisaran umur 65-74 tahun dengan $\mathrm{OR}=3,6$ (95\%Cl:1,5-8,9), sedangkan pada kisaran umur 75-84 tahun dengan $\mathrm{OR}=6,6(95 \% \mathrm{Cl}: 2,7-16,3)(15)$.

Berdasarkan jenis kelamin, hasil penelitian ini tidak menunjukkan adanya perbedaan yang bermakna antara laki-laki dan perempuan untuk kejadian gangguan fungsi kognitif. Namun apabila dilihat dari prevalensi gangguan fungsi kognitif, lebih banyak terjadi pada subjek perempuan sebanyak $11,1 \%$ sedangkan pada laki-laki sebanyak $9,1 \%$. Hal ini sesuai dengan hasil penelitian di Austria yang menyatakan bahwa wanita cenderung memiliki risiko lebih tinggi terhadap terjadinya gangguan fungsi kognitif dibandingkan laki-laki, di mana persentase untuk wanita yang mengalami gangguan fungsi kognitif $11,4 \%$ dan pada laki-laki 5,2\% (14). Hal ini disebabkan penurunan hormon estrogen pada perempuan menopause dapat meningkatkan risiko penyakit neurodegeneratif, karena hormon ini diduga memegang peranan penting dalam memelihara fungsi otak (16).

Status gizi tidak menunjukkan hubungan yang bermakna dengan fungsi kognitif, tetapi sebagian besar subjek mengalami malnutrisi. Berbeda dengan hasil penelitian di Swedia yang menyatakan bahwa fungsi kognitif berhubungan dengan status gizi $(p<0,03)(17)$. Perbedaan hasil penelitian ini disebabkan adanya perbedaan umur subjek yang digunakan. Pada penelitian tersebut umur subjek adalah $81 \pm 7$ tahun, sedangkan pada penelitian ini umur subjek yang digunakan lebih dari atau sama dengan 60 tahun. Jumlah subjek yang digunakan pada penelitian ini juga lebih sedikit dibanding penelitian sebelumnya. Selain itu terdapat perbedaan penggunaan indikator untuk penilaian status gizi, penelitian ini menggunakan BMA sedangkan penelitian sebelumnya menggunakan body mass index (BMI).

Penyakit yang berpengaruh terhadap kesehatan lanjut usia terutama terhadap fungsi kognitif antara lain hipertensi dan diabetes mellitus. Hasil penelitian ini menunjukkan bahwa 18 subjek mengalami hipertensi. Namun, hasil analisis memperlihatkan bahwa tidak terdapat hubungan yang bermakna antara hipertensi dengan kejadian gangguan fungsi kognitif pada lanjut usia $(p>0,05)$. Hasil penelitian ini berbeda dengan hasil penelitian di Amerika yang menyatakan bahwa hipertensi berhubungan dengan kerusakan khusus di fungsi bagian kepala pada kesehatan lanjut usia. Pengaruh dari hipertensi akan menyebabkan terjadinya tekanan pada perfusi serebral dan berdampak terhadap fungsi kognitif (18).

Pada penelitian ini, diabetes juga tidak menunjukkan adanya hubungan yang bermakna dengan fungsi kognitif $(p>0,05)$. Hasil yang berbeda dilaporkan dari penelitian di Amerika yang menyebutkan bahwa diabetes mellitus yang dialami seseorang selama lebih dari lima belas tahun akan meningkatkan risiko gangguan kognitif sebesar $50 \%$ dibandingkan dengan yang tidak mengalami diabetes (5). Perbedaan hasil penelitian ini disebabkan perbedaan lamanya seseorang dalam mengalami penyakit diabetes, pada penelitian di Amerika, diabetes akan meningkatkan risiko penurunan fungsi kognitif karena subjek mengalami diabetes dalam kurun waktu lebih dari lima belas tahun.

\section{Hubungan antara asupan zat gizi mikro dengan status kognitif}

Hubungan antara vitamin B6 dengan fungsi kognitif. Hasil analisis bivariat menunjukkan adanya hubungan yang bermakna antara asupan vitamin B6 dengan kejadian gangguan kognitif pada lanjut usia $(p<0,05)$. Hasil analisis diperoleh nilai $R P=2,514$, artinya subjek dengan asupan vitamin B6 kurang mempunyai peluang 2,514 kali untuk mengalami gangguan fungsi kognitif dibandingkan subjek dengan asupan vitamin B6 baik. Menurut hasil penelitian di Amerika, subjek dengan asupan B6 tinggi akan memperlihatkan performa kognitif yang lebih baik pada 2 tes memori (19).

Pada penelitian ini sebagian besar subjek tergolong dalam kategori asupan vitamin B6 baik. Status vitamin B6 dapat berpengaruh pada fungsi kognitif karena 
kekurangan vitamin B6 dapat mempengaruhi fungsi memori dan dapat berkontribusi pada gangguan fungsi kognitif. Defisiensi vitamin B6 dapat mengakibatkan gangguan pada konsentrasi homosistein. Peningkatan konsentrasi homosistein yang beredar dalam pembuluh darah merupakan faktor risiko aterosklerosis dan juga berpengaruh secara langsung pada neuron dalam sistem saraf pusat (19).

Hubungan antara folat dengan fungsi kognitif. Berdasarkan hasil analisis diperoleh tidak adanya hubungan yang bermakna antara asupan folat dengan fungsi kognitif pada lanjut usia $(p>0,05)$. Asupan folat sebagian besar subjek $(88,9 \%)$ tergolong kurang. Hal ini didukung oleh hasil penelitian di UK yang menyatakan bahwa rendahnya asam folat tidak berpengaruh terhadap volume otak yang hilang setiap tahunnya yang diteliti selama 5 periode pada populasi lansia (20).

Hasil penelitian di Rotterdam menunjukkan bahwa konsentrasi serum folat yang tinggi berpengaruh terhadap performa kognitif yang lebih baik pada tes kecepatan psikomotor, hubungan ini diperantarai oleh mekanisme vaskuler (21). Folat berperan dalam metabolisme satu karbon dan reaksi metal. Folat dibutuhkan untuk perubahan dari homosistein menjadi metionin. S-adenosylmethionine adalah donor metil primer pada pada beberapa reaksi yang dibutuhkan untuk fungsi otak normal, seperti pembentukan membran sel, phospolipid, neurotransmiter, dan myelin (4).

Hubungan antara vitamin $\mathbf{C}$ dengan fungsi kognitif. Hasil analisis menunjukkan adanya hubungan yang bermakna antara asupan vitamin $C$ dengan kejadian gangguan kognitif pada lanjut usia $(p<0,05)$. Berdasarkan hasil analisis diperoleh nilai $\mathrm{RP}=3,039$ artinya subjek dengan asupan vitamin $\mathrm{C}$ kurang mempunyai peluang 3,039 kali untuk mengalami gangguan fungsi kognitif dibanding subjek dengan asupan vitamin C baik. Hasil penelitian cohort di Asutralia menunjukkan bahwa konsumsi suplemen vitamin C bermakna terhadap rendahnya prevalensi gangguan kognitif (22). Vitamin C melindungi jaringan dari radikal bebas, yang merupakan penyebab gangguan fungsi kognitif pada lanjut usia. Antioksidan dari vitamin $\mathrm{C}$ kemudian mengubah radikal bebas menjadi radikal askorbil, lalu menjadi askorbat dan dehidroaskorbat. Asam askorbat berperan sebagai reduktor untuk radikal bebas yang secara langsung menangkap radikal bebas oksigen $(23,24)$.

Hubungan antara vitamin $E$ dengan fungsi kognitif. Berdasarkan hasil analisis diketahui bahwa adanya hubungan yang bermakna antara asupan vitamin $E$ dengan kejadian gangguan fungsi kognitif pada lanjut usia $(p<0,05)$. Penelitian yang sama dilakukan di Amerika dan menunjukkan bahwa asupan vitamin $E$ yang tinggi dari makanan berhubungan dengan rendahnya gangguan kognitif. Asupan vitamin E tinggi dari makanan diketahui berpengaruh dalam memperlambat penurunan fungsi kognitif yang dilihat pada skor fungsi kognitif yang diamati selama 6 tahun. Lansia dengan asupan vitamin $\mathrm{E}$ lebih besar atau sama dengan 100\% angka kecukupan gizi (AKG) menunjukkan kemampuan kognitif yang lebih baik $(25,26)$.

Vitamin E merupakan antioksidan yang kuat untuk membantu mencegah penurunan kognitif, dengan menyediakan perlindungan terhadap kerusakan jaringan saraf. Vitamin E berfungsi sebagai donor ion hidrogen yang mampu mengubah radikal peroksil menjadi radikal tokoferol yang kurang reaktif. Hubungan vitamin E dengan penurunan wfungsi kognitif dapat juga dikaitkan dengan sistem vaskular, di mana vitamin E mampu menurunkan risiko penyakit ateroskelerosis dengan cara melindungi LDL dari oksidasi (26).

\section{Analisis multivariat}

Berdasarkan hasil analisis bivariat, variabel bebas dan variabel luar yang masuk dalam analisis multivariat $(p \leq 0,25)$ yaitu vitamin $B 6$, vitamin $C$, vitamin $E$, dan hipertensi. Berdasarkan hasil analisis regresi logistik diketahui bahwa asupan vitamin $\mathrm{C}$ memiliki hubungan bermakna terhadap terjadinya gangguan fungsi kognitif $(p<0,05)$. Lansia dengan asupan vitamin $C$ kurang memiliki risiko 3,4 kali untuk mengalami gangguan fungsi kognitif (Nilai Exp (B)=3,428; 95\%Cl:1,114-10,552), .

Vitamin $\mathrm{C}$ merupakan antioksidan larut air dan dapat disintesis oleh tubuh sehingga pemenuhan kebutuhan dapat tercukupi dari asupan makanan. Pada penelitian ini kebutuhan vitamin $\mathrm{C}$ dapat terpenuhi karena subjek banyak mengonsumsi buah setiap hari sebagai sumber vitamin $\mathrm{C}$ diantaranya pepaya, pisang, jeruk, dan jambu, selain itu beberapa subjek juga mengonsumsi suplemen vitamin $\mathrm{C}$.

\section{KESIMPULAN DAN SARAN}

Terdapat hubungan yang bermakna antara asupan vitamin B6, vitamin $\mathrm{C}$, dan vitamin $\mathrm{E}$ dengan fungsi kognitif. Lansia sebaiknya mengonsumsi sumber-sumber zat gizi yang mampu mengurangi terjadinya penurunan fungsi kognitif dan menerapkan kebiasaan mengonsumsi makanan untuk menangkal radikal bebas yaitu makanan yang berasal dari buah-buahan, sayuran, kacangkacangan, dan minyak nabati yang disesuaikan dengan kondisi lansia.

\section{RUJUKAN}

1. Departemen Kesehatan RI. Pedoman penanggulangan masalah kesehatan intelegensia akibat gangguan degeneratif. Jakarta: Direktorat Bina Gizi Masyarakat DitjenBinkesmas Depkes RI; 2010.

2. Turana YM. Pemeriksaan status mini mental pada usia lanjut di Jakarta. Medika 2004;30(9):563-8. 
3. Requejo AM, Ortega RM, Robles F, Navia B, Aparicio A. Influence of nutrition on cognitive function in a group of elderly, independently living people. Eur J Clin Nutr 2003;57(1):S54-7.

4. Ramos MI, Allen LH, Mungas DM, Jagust WJ, Haan MN, Green R, Miller JW. Low folate status is associated with impaired cognitive function and dementia in the Sacramento Area Latino study on aging 1-3. Am J Clin Nutr 2005;82(6):1346-52.

5. Logroscino G, Kang JH, Grodstein F. Prospective study of type 2 diabetes and cognitive decline in women aged 70-81 years. BMJ 2004;328:548.

6. Madiyono B, Moeslichan S, Sastroasmoro S, Budiman I, Purwanto SH. Dalam: Sastroasmoro S, Ismael S. Dasardasar metodologi penelitian klinis. Jakarta: Sagung Seto; 2008.

7. Lumbantobing SM. Kecerdasan pada usia lanjut dan demensia. Jakarta: Balai Penerbit FKUI; 2001.

8. Almatsier S. Prinsip dasar ilmu gizi. Jakarta: Gramedia Pustaka Utama; 2009.

9. Rabe B, Thamrin MH, Gross R, Solomons NW, Schultink $W$. Body mass index of the elderly derived from height and from armspan. Asia Pac J Clin Nutr 1996;5(2):79-83.

10. Aswin S. Perubahan struktural dan fungsional otak menua strategi optimalisasi otak menua menuju hidup sehat. Kongres Nasional III dan Temu IImiah Nasional II, Medika. Yogyakarta: Fakultas Kedokteran UGM; 2004.

11. Lee S, Kawachi I, Berkman LF, Grodstein F. Education, other socioeconomic indicators, and cognitive function. Am J Epidemiol 2003;157(8):712-20.

12. Farmer ME, Kittner SJ, Rae DS, Bartko JJ, Regier DA. Education and change in cognitive function. Ann Epidemiol 1995;5(1):1-7.

13. Swanwick GR, Coen RF, Maguire CP, Kirby M, Walsh JB, O'neill D, Coakly D, Lawlor BA. The association between demographic factors, disease severity and the duration of symptoms at clinical presentation in elderly people with dementia. Age Ageing 1999;28(3):295-9.

14. Freidl W, Schmidt R, Stronegger WJ, Irmler $A$, Reinhart $B$, Koch M. Mini mental state examination: influence of sociodemographic, environmental and behavioral factors, and vascular risk factors. J Clin Epidemiol 1996;49(1):73-8.
15. Paul C, Ribeiro O, Santos P. Cognitive impairment in old people living in the community. Arch Gerontol Geriatr 2010;51(2):121-4.

16. Czlonkowska A, Ciesielska A, Joniec I. Influence of estrogen on neurodegenerative processes. Med Sci Monit 2003;9(10):247-56.

17. Irving GF, Olsson BA, Cederholm T. Nutritional and cognitive status in elderly subjects living in service flats, and the effect of nutrition education on personal. Gerontology 1999;45:187-94.

18. Grodstein F, Chen J, Willett WC. High-dose antioxidant supplements and cognitive function in communitydwelling elderly women. Am J Clin Nutr 2003;77(4):97584.

19. Riggs KM, Spiro A, Tucker K, Rush D. Relations of vitamin B-12, vitamin B-6, folate and homocysteine to cognitive performance in the normative aging study. Am J Clin Nutr 1996;63(3):306-14.

20. Smith $A D$, Smith $S M$, Jager $C A$, Whitbread $P$, Johnston C, Agacinski G, Oulhaj A, Bradley KM, Jacoby R, Refsum $\mathrm{H}$. Homocysteine-lowering by $\mathrm{b}$ vitamins slows the rate of accelerated brain atrophy in mild cognitive impairment: a randomized controlled trial. PLoS One 2010;5(9):1-10.

21. De Lau LML, Refsum H, Smith AD, Johnston $C$, Breteler MMB. Plasma folat concentration and cognitive performance: Rotterdam scan study. Am J Clin Nutr 2007;86(3):728-34.

22. Paleologos M, Cumming RG, Lazarus R. Cohort study of vitamin $\mathrm{C}$ intake and cognitive impairment. $\mathrm{Am} \mathrm{J}$ Epidemiol 1998;148(1):45-50.

23. Young LS, Woodside JV. Antioxidant in health and disease. J Clin Pathol 2001;54:176-86.

24. Winarsi H. Antioksidan alami \& radikal bebas. Yogyakarta: Kanisius; 2007.

25. Morris MC, Evans DA, Tangney CC, Bienias JL, Wilson RS, Aggarwal NT, Scherr PA. Relation of the tocopherol forms to incident alzheimer disease and to cognitive change. Am J Clin Nutr 2005;81(2):508-14.

26. Aparicio A, Bermejo LM, Rodriguez ER, Andres $P$, Ortega RM, Sobaler AML. Influenced of vitamin E status on cognitive function in elderly people. Elderly Nutrition 2006;19(6):30-2. 